\title{
THE ROLE OF THE TEACHER IN INTERACTIVE TEACHING
}

MSc Arbona Xhemajli, PhD candidat, Faculty of Philosophy-Pedagogy,

Ss. Cyril and Methodius University, Skopje, Macedonia

E-mail: arbona.xhemajli@hotmail.com

\section{A R T I C L E I N F O}

Original Article

Received: March, 13.2016.

Revised: April, 18.2016.

Accepted: April, 27.2016.

doi:10.5937/IJCRSEE1601031X

UDK

371.311 .4

\section{Keywords:}

teacher's role,

pupil,

interactive teaching,

applied.

\begin{abstract}
A B S T R A C T
Considering the role of the teacher and their relation to pupils during the instructional process as well as the organisation of activities by the teacher, this paper actualises the current views related to the role the teacher has in interactive teaching.

The teacher is the basic instigator of interaction with his/her pupils and he/ she can be such an instigator only with well organised teaching.

Interactive teaching, a promising approach, represents a challenge not only for the teachers but for the professional service as well. The traditional teaching, dominated by a verbal approach and memorising of the teaching material, is entirely replaced with other activities, both in the process of following the teaching and in the process of learning the material.

The purpose of this paper is to explore the level of application of interactive teaching in the educational process, since practicing of interactive teaching by the teachers, during this paper represents only a part of authentic results from the two combined researches, one part of results obtained via survey sheets given to the teachers of nine schools and a part of the results from interviews taken with the professional service as a focus group.
\end{abstract}

(C) 2016 IJCRSEE. All rights reserved.

\section{INTRODUCTION}

Apart from the development of the pedagogical thought, teachers' work has always been in the focus of interest of renowned scholars who emphasise various aspects related to the role and the position of teachers.

Application of interactive teaching within a class also dictates a change of the teacher's role.

Such a change requires the teacher to possess knowledge, to be an educator, advisor, friend, organiser, coordinator, associate, assessor, in a word, to be a versatile person. More specifically, the teacher has a wider and more versatile role in interactive teaching. He/ she should be active in school, outside school,

Corresponding Author

MSc Arbona Xhemajli, Faculty of PhilosophyPedagogy, Ss. Cyril and Methodius University, Skopje, Macedonia, E-mail; arbona.xhemajli@hotmail.com

\section{(i) $\odot$}

This work is licensed under a Creative Commons Attribution 4.0 International license. The article is published with Open Access at www.ijcrsee.com during the after school activities and in the implementation of cultural activities in school. A good teacher does not impose his/her attitudes, however, his/her role also imposes on him/her to cooperate with pupils. Cooperating with pupils does not imply that the teacher should only listen to their proposals. Good and democratic work in a class implies that the teacher accepts the influence by the pupils.

With interactive teaching, the pupil is positioned in the role of a subject and equal partner of the teacher. Teachers who respect their pupils and the pupils' opinion organise the teaching process in a way in which the pupils acquire knowledge more easily and at the same time, they instigate pleasure and curiosity in them during the implementation of the programme contents.

This paper mentions, explains and analyses the terms that are crucial in the determination of the subject of the paper. This excludes the possibility for them to be understood incorrectly or differently. The basic terms that appear in the title are:

- Interactive teaching;

- The teacher and his/her role.

There are many definitions of the term 
interactions, which basically differ according to the interpretation of this term, however, they are put into the context of sources that have a pedagogical character, in which the interaction is more based on the teaching. In the Pedagoški leksikon (2000, p. 203), interaction is interpreted as something of a wider scope, in the context of philosophy, dialectics and of a number of special theories in different sciences. Still, the basic starting point is the definition according to which "interaction is defined as a general term for various types of mutual action between two or more systems."

Bratanić states that interactions as an actual relation are seen through mutual action of persons who mutually define their behaviour based on the attitudes they assume one towards the other. If we have pointed out that there is no education without interpersonal relations, now we can emphasise that there is no education without interaction (Bratanić, M., 1993, p. 76).

Roth defines interaction as an "actual relation between two or more individuals, whereby one individual influences the conduct of the other individual." The term interaction implies "mutual action of people who assume attitudes one to another, which bilaterally defines the conduct" (Roth, N., 1973, p. 11).

From the historical point of view, until the middle of the $1980 \mathrm{~s}$, literature related to the interaction teacher-pupil most frequently addressed the aspects of studies of Pianta, Hamre and Stuhlman, while the last thirty years shifted the interest of researchers towards the relation between the pupil and the teacher (Pianta, R.C., Hamre, B. and Stuhlman, M., 2003, pp. 199-234).

Because, when it comes to school education we distinguish $\backslash$ the terms learning (the activity undertaken by the pupil) and teaching (the activity undertaken by the teacher), two processes that are interrelated, we will define below the term interactive teaching.

Interactive teaching implies learning with action. It is characterised with a high level of inclusion of the pupil. The basics of interactive teaching can be found in constructivism, which interprets the learning as a process of reflection through personal experience. The interactive learning requires the teacher to play the role of a trainer and an assistant, who use their real experience and at the same time are supposed to have patience or expectations that pupils will achieve a certain level of quality (Musai, B., 2014, p.52).

The Glossary of Education by Kosma Grillo states that interactive teaching is a pro- cess of learning that is actuated by the interest of the pupil and the procedures for reviewing (Grillo, K., 2002, p.304).

Interactive teaching within the process of education is a level of learning with cooperation since the set educational goals and assignments are successfully accomplished within the pupils' joint work. For that reason, the phenomenon active - interactive is a constituent part of the modern strategy of organising and maintaining all the forms of instructional work and its modalities.

According to Zylfi, interactive teaching as part of the global strategy of the system of operation of the teaching methods is an active model of learning in the contemporary school that has support in the process of development of the problem of learning with research elements. With interactive learning, the cooperative elements raise the quality of knowledge (Zylfi, N., 2011, p. 239).

Interactive teaching implies offering of possibilities to pupils so that speech, listening, writing and reading have full meaning and reflect on the contents, ideas, and problems of one specific academic subject (Meyers and Jones, 1993, p.6).

The role of the teacher has been discussed constantly, since the very beginning of school; there is no pedagogical issue that is not about the teacher. According to Bardhyl Musai, we usually employ the term teacher for persons who have a main, functional and professional task to help others in gaining knowledge and acquiring habits as well as new ways of conduct (Musai, B., 2014, p.3).

The Pedagogical Lexicon gives a narrow definition of the term teacher as a person qualified to carry out instruction, to perform educational and vocational work with children, youth and adults.

Pedagogue Zylfiu states that the term teacher is understood to imply qualified educational staff, who teach and are directed by their own wish and will towards the execution of the educational and vocational work, which is the work that requires a high level of responsibility (Zylfiu, N., 2011, p.239).

Zeiger (2014) pointed out that the role of the teacher implies much more than standing before the pupils and only teaching. A good teacher in instruction implies a large number of activities, which he/she performs in order to ensure that all the children receive quality instruction.

In his book titled "Methodology of Teaching," Musai (2003) wrote that the teacher is a person assigned with the task to help others to learn and behave in a certain 
way, different from the old way of behaviour. According to Lanier (2015), the most important task of the teacher is to make effort to enable well understandable teaching experience, which enables the pupils to resolve problems from the real life and demonstrate that they have learned great ideas, acquired good capabilities and fulfil the laws of the mind and the heart, complying with educational standards.

Rice (2003) reveals that good teachers highlight the importance of independence of the pupils and encourage them to express their imagination. Pupils are motivated to learn from contents or lessons adjusted to their interests and inspiration. This implies that the teachers have influence and responsibility for the formation of pupils as persons. With such an influence and responsibility, they feel great honour and joy. That is why all the teachers should strive to be good teachers.

\subsection{The Role of the Teacher in Traditional Teaching}

Teacher's profession is one of the oldest professions that originate from the period before the establishment of school as an institution. Persons who enjoyed respect in the society were selected for this dignified profession. The level of acquired pedagogical knowledge greatly depends on the teacher himself/herself and his/her professional competences. The teacher is always expected to be a role model for the pupils and the society as a whole with his/her conduct and education and work. The type of activities that the teacher will be able to perform successfully and the objective of the activities themselves depend on the level of such competences.

The role of the teacher in the traditional system of teaching proved to be ineffective and inadequate for the pupils. The teacher in the traditional way of teaching appeared as the main agent of the educational and vocational activities in school. In such type of teaching, he/she is the agent of the activities in the class. The teacher appears in the role of the provider of information, i.e. the lecturer who relies on books. Changing the teacher's role from a passive doer to an active doer is hard work due to the traditional practice applied for a long time; at the same time, there is inertia among the teachers to open towards the latest trends and developments.

Interactive teaching is a challenge to teachers since they are required to change the way of work and at the same time possess a high level of professional preparedness.

\subsection{The Role of the Teacher in Interactive Teaching}

The teacher in interactive teaching does not have only educational and vocational role but he/she has to be a designer, programmer, diagnostician, researcher, organiser, manager, innovator, educator and advisor (Ilić, M., 1999, p.141). More specifically, the teacher is the organiser of teaching and partner during the communication with his/her pupils.

For the needs of contemporary schools, William Glasser shows the path for achieving high quality education, which will not be based on compulsion and the authoritative style of the teacher. During this process, the managing role of the teacher should change (Glasser, W., 1994 p. 25). According to this author, the teacher who manages to make all his/her pupils be active during the teaching process may be regarded as an interactive teacher. The author also emphasises that teaching is a difficult activity, which should meet the need of the pupils. For productive work and motivation of pupils it is important to create positive environment in the classroom, which will stimulate satisfaction with the pupils, along with their curiosity to learn.

Unlike traditional teaching, where great attention is dedicated to the teaching contents, interactive teaching pays greater importance to the way in which knowledge is acquired.

An interactive teacher is the one who respects all the pupils, listens to them and helps them to solve problems by themselves, as well as to mutually exchange good ideas with the way of his/her actions and his/her attitudes. The same importance is given to the posture and the conduct of the teacher, which are as important as the activities that the teacher carries out with children. An interactive teacher is the one who knows and understands some basic principles related to how the child studies and at the same time, knows to use different forms and methods related to the teaching, in order to help all children.

By applying interactive teaching, the relations between the pupils become friendlier, better understanding of the common goal is enabled, communication is open and at the same time, better results in mastering teaching contents are achieved.

Application of interactive teaching is not an easy job. Most teachers are used to carry- 
ing out teaching in the way they were thought when they were pupils, complemented with the acquiring of certain additional knowledge when they completed the Faculty of Pedagogy, as well as through various trainings. Changing of old habits of teaching and seeking new ways is pretty difficult since we do not know how to come to interactive teaching and what is its objective.

Creation of possibilities for interactive teaching requires teachers to get acquainted with several strategies in order to facilitate and support the communication between the pupils. It means that the teachers should know and to be capable of using interactive models in which pupils are frequently involved in small and large group activities.

Interactive teaching requires better professional qualification from teachers, along with greater engagement. In order to apply successfully interactive teaching in the classroom, the teacher should plan and prepare the teaching activities in advance.

\section{MATERIALS AND METHODS}

This survey included 151 teachers from nine elementary schools. Questionnaires for the teachers were prepared in accordance with the Likert scale. The results were processed based on the working experience in the educational sector and the teachers' educational background.

This paper also presented some of the results of the discussions within the focus groups with professional service - inspectors, teachers, and principals. Selection of participants in focus groups was deliberate because all participants have experience with observation during the teaching process and based on their experience to discuss the topic under study.

\subsection{Research Hypotheses}

There is a significant difference between teachers and the professional service with regard to practising interactive teaching in the educational work with children in early school age.

\section{RESULTS}

Teachers and pupils are direct participants in interactive teaching; still, principals and professionals in school (pedagogues, psy- chologists) play a significant role in the organisation of interactive teaching.

Therefore, in highlighting this topic, we are of opinion that it is important to include the interview with the focus group composed of principals, inspectors and pedagogues.

On the question: To what extent is interactive teaching practised in the educational work with children in the early school age?

Members of the focus group gave the following responses:

\section{Direct quotes}

D-1: It is easier for teachers to work in a traditional way, therefore they practise interactive teaching to a low extent.

D-2: Interactive teaching is practised more by trained teachers who know how to apply this type of teaching. Teachers try to apply interactive teaching through certain activities that are organised within the class, but such teaching is not on a satisfactory level.

D-3: I do not think that we are at the beginning of the journey; however, there is a lot to be done in the direction of application of interactive teaching.

D-4: Interactive teaching is not applied on a satisfactory level. Failure to apply interactive teaching in practice results from the failure of the institutions to oblige teachers to apply interactive teaching, giving them freedom in their work. Teachers only prepare for interactive teaching when they know that they will be monitored.

D-5: Interactive teaching is applied more in preschool classes than in the first grade of elementary education.

D-6: We are in the first phase of application of interactive teaching and therefore we should be concerned about the non-implementation of this type of teaching, knowing its positive effects.

D-7: Some teachers, although trained and qualified, do not apply interactive teaching. During the training in interactive teaching, it was applied more frequently, and after the completion of the training sessions, i.e. the project, the application of interactive teaching declined.

D-8: In our schools, interactive teaching is not applied on an adequate level, and contemporary teaching methods are not applied, all this because of the following two reasons:

- Curricula are not prepared to enable implementation of the interactive teaching.

- School texts are prepared in the 
manner that they are more adjusted to the traditional way of teaching.

D-9: Working in groups requires special assignments to be prepared for each group and therefore teachers are not motivated to prepare various assignments and they are oriented towards frontal work. Very often, the organisation of the class does not allow interactive teaching.

D-10: Teachers of different generations are engaged in schools that are the subject of this survey, which makes it visible that aged teachers practise interactive teaching less since it is difficult for them to change their way of work.

On the other hand, teachers that participated in the survey rated the question «how much do you practise interactive teaching in the work with the children in the early school age" with an average grade of 4.09 , meaning that the teachers confirmed that during their work with the children they employ interactive teaching on a very high level.

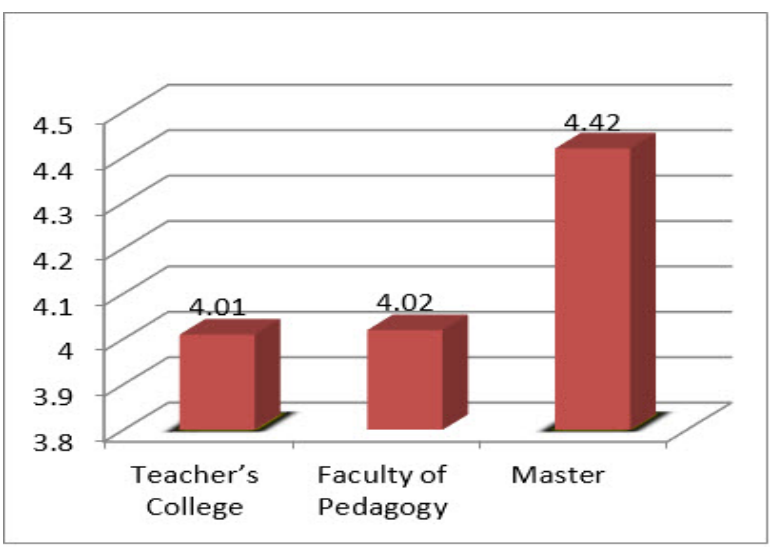

Graph 1. Graphic presentation of the results to the question:How much do you practise interactive teaching in your work with children, according to the level of education

Regarding this issue, the results obtained on the basis of the working experience in the educational sector were also analysed.

Teachers with the working experience of up to 5 years assessed interactive teaching with the average grade of 4.13 ; their colleagues with the working experience from 5 to 10 years gave the average grade of 4.09 ; those with the working experience from 11 to 20 years in relation to practising interactive teaching gave the average grade for the interactive teaching of 4.12; while teachers with working experience above 20 years, answering the same question, gave the average grade of 4.04 .

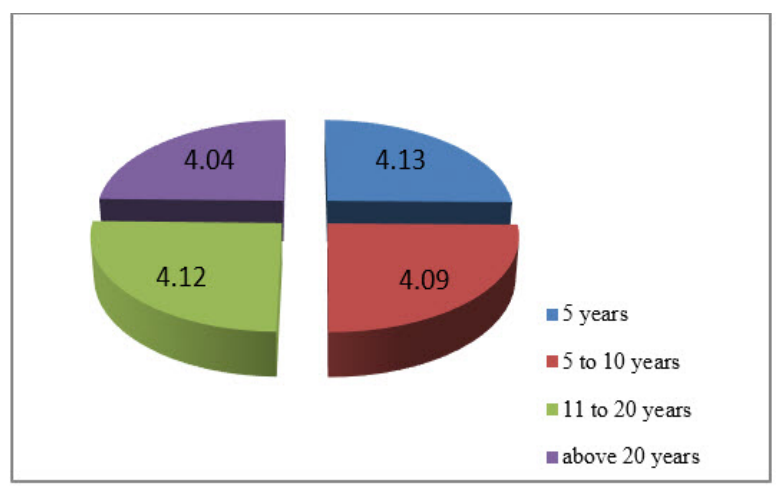

Graph 2. Graphic presentation of the results for the question: How often do you practise interactive teaching in the work with children from the early school age, according to the working experience in the educational sector

\section{DISCUSSION}

Referring to data obtained with the help of professional workers as a focus group, they gave unsatisfactory attitudes in relation to the application of interactive teaching in the educational and vocational work.

Professional workers confirmed that during their educational and vocational work they employ interactive teaching, but not to a great extent. According to them, interactive teaching does not apply sufficiently due to the following reasons:

- Adult - traditional teachers have difficulties to employ interactive teaching, compared to younger teachers, who participate in various trainings for that goal.

- In the period when training for interactive teaching was carried out, it was practised to a greater extent but as soon as the project finished, the application of interactive teaching started to decrease, and the same happened after other trainings.

- Failure to employ interactive teaching in practice is a consequence of the institutions not obliging the teachers to apply interactive teaching, giving them freedom in their work. Teachers prepare for interactive teaching only in cases when they know that they are going to be supervised.

- School texts are prepared in such a way that they are more adjusted to the traditional way of teaching.

- The work in groups requires spe- 
cial assignments for each group and therefore, teachers are not motivated to prepare various assignments and they are oriented towards frontal work.

- There is inertia among teachers and schools concerning opening towards the latest trends and developments.

The obtained data demonstrate that teachers with completed Teacher's College with regard to the employment of interactive teaching gave the average grade of 4.01 , their colleagues who completed the Faculty of Pedagogy gave the average grade of 4.02 to the same question, while the those with the Master degree, rated interactive teaching, according to the Likert scale, with the average grade of 4.42. It can be concluded from the obtained results that teachers with higher qualifications practise interactive teaching to a higher extent.

\section{CONCLUSION}

From the grades of the teachers, we can conclude that they employ interactive teaching with the average grade of 4.09 , and professional workers confirm that they practise interactive teaching but not to a sufficient level. In case of their grading, there is a significant difference between the teachers and the professional service, related to practising interactive teaching in the educational and vocational work with children.

From the results obtained with this study, we can establish that teachers with the highest qualifications employ interactive teaching to the highest extent, while teachers with the longest working experience in the educational sector and their colleagues at older age employ interactive teaching with children to the lowest extent.

The results from the research confirmed that the main burden is on the teacher and the way in which he/she organises the work in the classroom. In order that interactive teaching in the classroom is successfully employed, the activities should be planned and prepared in advance.

\section{Recommendations}

Based on the obtained results, we are giving the following recommendations:

- Any teaching subject can be interactive, it only requires greater commitment from the teacher;

- Interactive teaching should not be treated and studied only when study objectives are in question, it should be employed more in the classroom;

- Organising joint meetings with the teachers where the importance of interactive teaching will be discussed;

- Mutual visits and exchange of experience among teachers should be realised;

- Presentation of teachers who practise interactive teaching should be made;

- Instructions for the teachers (related to the models of teaching) should be prepared;

- Interactive teaching has a large number of advantages compared to the traditional way of teaching and therefore, it should be employed more by the teachers.

\section{ACKNOWLEDGMENTS}

This paper wouldn't have been compiled together without the moral and intellectual support of Prof. Dr. Lena Damovska to whom we express our infinite gratitude for her time and effort invested in us.

We would also like to express our gratitude to the teachers from elementary schools that were a part of the survey, as well as to the members of the focus groups whose replies contributed for this paper to be more comprehensive and richer.

\section{Conflict of interests}

The author declare no conflict of interest.

\section{REFERENCES}

Bennett, N., \& Cass, A. (1989). The effects of group composition on group interactive processes and pupil understanding. British Educational Research Journal, 15(1), 19-32.

Bezić, K., \& Strugar, V. (1998). Učitelj za treće tisućljeće. Zagreb: Hrvatski pedagoškoknjiževni zbor:

Bratanić, M. (1993). Mikropedagogija: Interakcijskokomunikacijski aspekt odgoja. Zagreb: Školska knjiga.

Breidenbach, L., \& Killion, J. (2001). What works in the middle: Results-based staff development.Oxford, $\mathrm{OH}$ : National Staff Development Council.

Caena, F. (2014). Teacher Competence Frameworks in Europe: policy as discourse and policy as practice. European Journal of Education, 49(3), 311-331.

Cassaday, H. J., Bloomfield, R. E., \& Hayward, N. (2002). Relaxed conditions can provide memory 
cues in both undergraduates and primary school children. British Journal of educational psychology, 72(4), 531-547.

Cindrić, M. (1995). Profesija učitelj u svijetu i u Hrvatskoj. Zagreb, Persona.

Delors, J. (1998). Učenje: Blago u nama. Zagreb: Educa.

Dryden, G., \& Vos, J. (2001). Revolucija u učenju. Educa, Zagreb.

Giesecke, H. (1993). Uvod u pedagogiju [Introduction to pedagogy. In Croatian]. Zagreb: Educa.

Glasser, W. (1994). Kvalitetna skola. Educa Zagreb.

Goleman, D. (1997). Emocionalna inteligencija: zašto može biti važnija od kvocijenta inteligencije. Mozaik knjiga.

Gossen, D., Anderson, J., Paić-Jurinić, M., \& Š́urić, L. (1996). Stvaranje uvjeta za kvalitetne škole. Alinea.

Grillo. K. (2002). Fjalor edukimi. Tiranë: Instituti i studimeve pedagogjike.

Havelka, N. (2000). Učenik i nastavnik u obrazovnom procesu. Zavod za udžbenike i nastavna sredstva.

Ilić M. (1999). Komunikacija između učenika i nastavnika, U zborniku Pedagoška reforma škole, Beograd: Ruska akademija obrazovanja i Zajednica učiteljskih fakulteta Srbije.

Lanier, J. (2012). Redefining the role of the teacher: It's a multifaceted profession. Retrieved on 4th November.2015, from: http:www.edutopia.org/ redefining-role-teacher.

Meyers, C., \& Jones, T. B. (1993). Promoting Active Learning. Strategies for the College Classroom. Jossey-Bass Inc., Publishers, San Francisco.

Musai, B. (2003). Metodologji e mësimdhënies. Tiranë: CDE.

Musai, B. (2014). Metodologji e mësimdhënies. Tiranë: CDE.

Osmić, I. (2001). Komunikacije i interakcije u nastavnom procesu: Sukob ili saradnja. Univerzitet. Tuzla: Grafičko-izdavačka društvo „Grin“.

Pedagoški leksikon (2000). Beograd: Zavod za užbenike i nastavna sredstva.

Pianta, R. C., Hamre, B., \& Stuhlman, M. (2003). Relationships between teachers and children. Handbook of psychology. New Jersey: John Wiley \& Sons.

Rice, J. K. (2003). Teacher quality: Understanding the effectiveness of teacher attributes. Economic Policy Institute, Washington, DC.

Rickards, T., Newby, M., \& Fisher, D. (2000). Teacher and student perceptions of classroom interactions: A multi-level model. Paper presented at Proceedings Western Australian Institute for Educational Research Forum.

Rijavec, M. (2001). Odgoj za razvoj. Zagreb: Alinea.

Rot, N. (1973). Osnovi socijalne psihologije, Beograd: Zavod za udžbenike i nastavna sredstva.

Tomas, G. (1998). Kako biti uspešan nastavnik. Kreativni centar i most, Beograd.

Vood, D. (1996). Kako djeca uče i misle. Zagreb: Eduka.

Zeiger, S. (2014). Raising Confident Kids. CreateSpace Publishing United States.

Zylfiu, N. (2011). Teoria e mësimit dhe proceset didaktike të mësimdhënies, Prishtinë: Printig Press. 